\title{
Obstetric complications and gestational age of presentation in pregnant adolescents
}

\begin{abstract}
Objectives: Identify obstetric and perinatal complications in pregnant adolescents and the gestational age of presentation.

Material and methods: Transversal descriptive study in pregnant adolescents, all those who over the years 2015-2017 presented pregnancy were studied. We studied prevalence and gestational age of presentation of obstetrics complications as abortion, urinary tract infection, cervicovaginal infection, preeclampsia/eclampsia, premature rupture of membranes, preterm labor; also we evaluated the condition of the product to the birth as weight, apgarpunctuation, prematurity, hyaline membrane and jaundice. The statistical analysis included confidence interval.

Results: The urinary tract infections prevalence is $40.5 \%$ (CI 95\%; 30.9-50.1), at 20.42 weeks (CI 95\%; 17.69-23.15), abortion prevalence is $22.7 \%$ (IC 95\%; 14.4-31.0) at 9.69 weeks (CI 95\%; 8.48-10.9), and premature rupture of membranes is $7.0 \%$ (IC 95\%; 1.9 $12.0)$ at 35.29 weeks (CI 95\%; 30.86-39.71).
\end{abstract}

Conclusions: The obstetric complications prevalence and gestational age of presentation in pregnant adolescents was identified.

Keywords: obstetric, complications, pregnant, adolescents

\author{
Volume 3 Issue 6 - 2019
}

\author{
Gabriela Avalos Arroyo, ${ }^{1,2}$ Enrique Villarreal \\ Ríos,' Leticia Blanco Castillo, ${ }^{3}$ Emma Rosa \\ Vargas Daza,' Liliana Galicia Rodríguez,' Lidia \\ Martínez González' \\ 'Unidad de Investigación Epidemiológica y en Servicios de Salud \\ Querétaro, Instituto Mexicano del Seguro Social, México \\ ${ }^{2}$ Residencia de Medicina Familiar, Unidad de Medicina Familiar \\ No 16 Querétaro, México \\ ${ }^{3}$ Unidad de Medicina Familiar No 9 Querétaro, Instituto \\ Mexicano del Seguro Social Querétaro, México
}

\begin{abstract}
Correspondence: Enrique Villarreal Ríos, Unidad de Investigación Epidemiológica y en Servicios de Salud Querétaro, Instituto Mexicano del Seguro Social, México, Zaragoza y 5 de Febrero Colonia Centro, CP 76000,Tel 4422 II 2300 ext 5III3,Email enriquevillrrealrios@gmail.com, enrique.villrreal@ imss.gob.mx
\end{abstract}

Received: October 16,2019 | Published: November 05, 2019

\section{Introduction}

The adolescent pregnancy continues to be a global public health problem, is a risk pregnancy, due to his physiological condition of immaturity and the complications that can arise, these have different behavior in pregnant adult age. ${ }^{1,2,3}$ Among the complications of pregnancy have been identified the prevalence of urinary tract infection, abortion, prematurity and preterm labor, however, the prevalence and gestational age of presentation in pregnant adolescents is unknown. ${ }^{3,4,5,6}$ In this context, the objective of this study is to identify obstetric and perinatal complications in pregnant adolescents, as well as the gestational age of presentation of such complications.

\section{Methods}

A transversal descriptive study was conducted on pregnant adolescents from 10 to 19 years of age, belonging to the medical unit of an institution of social security of the state of Querétaro, Mexico the information corresponded to the years 2015-2017. We included all those that took prenatal care with resolution of pregnancy within the institution; deleted cases with incomplete information in the clinical record and those who lost their force of law to the institution. The study population included 101 pregnant adolescents who represented the total of the population served with this feature during this time period. Socio-demographic variables were studied (on stage of prenatal care, gestational age at onset of prenatal care, schooling, occupation, marital status, socioeconomic status); presence and time of presentation of obstetric complications, product features (weight, size, apgar punctuation at minute $/ 5$ minutes) and presence of perinatal complications. Using the census as a sampling frame for pregnant adolescent patients, we used the reference number of the record and we attended the electronic file where the information was obtained. The statistical analysis plan included averages, percentages, confidence intervals for averages and confidence intervals for percentages. The protocol was registered before the local committee of research and fast to the ethical principles of the Helsinki declaration.

\section{Results}

Antenatal care in the studied population begins in the 14.38 weeks of gestation (CI 95\%; 12.74-16.02), the average age is of 17.16 years (CI 95\%; 16.82-17.49), has life as a couple 53.5\%(IC 95\%; 43.863.2), remunerated economic activity is present in $39.4 \%$ (CI $95 \%$; $29.1-48.1$ ), schooling is complete high school or more in $39.6 \%$ (CI $95 \% ; 30.1-49.1)$, and the family type according to a worker occupation is $79.2 \%$ (CI 95\%; 71.3-87.1). The obstetric complications with the highest prevalence is urinary tract infection with $40.5 \%$ (CI95\%; $30.9-50.1$ ), followed by the cervicovaginitis with $33.6 \%$ (IC $95 \%$; 24.2-43.0) and abortion with $22.7 \%$ (IC 95\%; 14.4-31.0). The Table 1 presents the rest of obstetric complication in the adolescent. The presentation of cervicovaginitis gestational age is 20.71 weeks (CI $95 \% ; 17.74-24.13)$, and the average gestational age of abortion is 9.69 weeks (CI 95\%; 4.48-10.90). The Table 2 identifies the gestational age for the presentation of obstetric complications in adolescents. Resolution of pregnancy through vaginal birth is $48.5 \%$ (CI 95\%; 38.8-58.2) with 38.54 (CI95\%; 38.07-39.01) weeks of gestation, caesarean section is of $28.7 \%$ (CI $95 \%$; 19.9-37.5) with 37.81 (CI $95 \% ; 36.90-38.71$ ) weeks of gestation, the rest of pregnancies resulted in abortion. The $89.8 \%$ (CI95\%; 83.9-95.7) of the newborns are of term, $6.1 \%$ (CI 95\%; 1.4-10.8) are preterm and the $4.1 \%$ (CI 95\%; 
0.2-8.0) posterm. The average birth weight is 2995.76 grams (CI95\%; 2888.49-3103.05). The rest of the anthropometric characteristics and evaluation of apgar are presents on Table 3 . The $7.0 \%$ (CI 95\%; 1.9 12.12) of the newborn babies have low weight at birth and the $59.8 \%$ (CI 95\%; 50.2-69.4) of the newborn infants correspond to male. In Table 4 presents other complications of the newborn nanny of teenage mothers.

Table I Prevalence of obstetric complications in adolescents

\begin{tabular}{llll}
\hline Variable & Percentage & CI 95\% & \\
\hline & & Lower & Upper \\
\hline Urinary tract infection & 40.5 & 30.9 & 50.1 \\
Cervicovaginitis & 33.6 & 24.2 & 43 \\
Abortion & 22.7 & 14.4 & 31 \\
Threat of preterm birth & 7.9 & 2.6 & 13.2 \\
$\begin{array}{l}\text { Premature rupture of } \\
\text { membranes }\end{array}$ & 7 & 1.9 & 12 \\
Preterm delivery & 3.9 & 0.1 & 7.7 \\
Preeclampia/Eclapmsia & 2 & 0 & 4.7 \\
\hline
\end{tabular}

Table 2 Average gestational age of obstetric complications in adolescents

\begin{tabular}{llll}
\hline Variable & Average (WOG)* & Cl 95\% & \\
\hline & & Lower & Upper \\
\hline Urinary tract infection & 20.42 & 17.69 & 23.15 \\
Cervicovaginitis & 20.71 & 17.74 & 24.13 \\
Abortion & 9.69 & 8.48 & 10.9 \\
Threat of preterm birth & 31.51 & 28.05 & 34.98 \\
Premature rupture of & 35.29 & 30.86 & 39.71 \\
membranes & 33.1 & 28.55 & 37.65 \\
Preterm delivery & 34 & -- & -- \\
Preeclampia/Eclapmsia & 34 & & \\
\hline
\end{tabular}

*Weeks of gestation.

Table 3 Anthropometric characteritics and assesment of apgar puntuation in the newborn of teenage mothers

\begin{tabular}{llll}
\hline Variable & Average & Cl 95\% & \\
\hline & & Lower & Upper \\
\hline Weight (grames) & 2995.76 & 2888.49 & 3103.05 \\
Size (centimeters) & 49.36 & 48.88 & 49.84 \\
Apgar at minute & 8.67 & 8.53 & 8.81 \\
Apgar at 5 minutes & 8.99 & 8.96 & 9.01 \\
\hline
\end{tabular}

Table 4 Perinatal complications in the newborn of teenage mothers

\begin{tabular}{llll}
\hline Variable & Percentage & Cl 95\% & \\
\hline Low weight & 7 & Lower & Upper \\
Neonatal jaundice & 7 & 1.9 & 12.2 \\
$\begin{array}{l}\text { Prematurity } \\
\begin{array}{l}\text { Hyaline membrane } \\
\text { dissease }\end{array}\end{array}$ & 5.1 & 1.9 & 12.2 \\
& 2 & 0.8 & 9.4 \\
\hline
\end{tabular}

\section{Discussion}

The importance of studying obstetric and perinatal complications, as well as gestational age which occur in pregnant adolescent patients, will allow first contact physician treat and anticipate them appropriately; another important point is that it is very little studied, due to the biopsychosocial complexity of this age group. ${ }^{7,8,9}$ The present study shows that the antenatal care in the studied population starts in the second trimester of pregnancy, unlike other countries in which the first consultation occurs in the third trimester; ${ }^{1}$ it is possible that this is due to cultural situations due to the lack of access to health services, networks of support, or the negation of the same teenager in their situation of pregnancy. ${ }^{6}$ Little more than half of the patients in this study have life as a couple, which is different compared to other South American countries; ${ }^{10}$ also due to cultural differences since the Mexican population still is conceived that the only form of reproduction is by living together as a couple regardless of the formality of the event. According to the occupation of the supplier the family type is a worker, due to the economy development of the State of Queretaro has had an increase in the industrial field in recent years, compared with States in the South of the country and other countries of the third world dominated by primary activity such as agriculture. ${ }^{5}$ This suggests that regardless of the occupation of the family, the teenager around the pregnancy behaves in the same way in third world countries and developing.

Faced with this panorama is considered necessary reinforcement in the education for the prevention of pregnancy in adolescents, since this work and student life in this sector is truncated and therefore creates a vicious circle in which poverty and ignorance is perpetuated. ${ }^{11}$ Within the obstetric complications of urinary tract infections are still prevalent due to physiological changes given during pregnancy, however, in this study it was observed more than 4 times compared to the rest of pregnant women in other countries, ${ }^{12,13,14}$ is probably that they do not have appropriate habits of self-care and, moreover they does not know in time identifying symptoms associated with urinary tractinfection. ${ }^{1}$ This last factor could change at the time of the detection of pregnancy with advice about your condition of vaginal and urinary tract infections, with an emphasis on the timely attention of the symptoms, in other words, health education; it is also noted that this complication occurs halfway through the pregnancy, what makes think that before the manifestation of urinary symptoms, most likely the adolescent patient studied with asymptomatic bacteriuria and was not treated. In this respect there is no reports mentioning the gestational age of presentation of urinary tract infections in pregnant women.

The cervicovaginitis presents a high incidence in this study, there is no record in the literature of prevalence of this condition, however, coincides with the gestational age of presentation of urinary tract infections, concluding that they go hand and even one may be causing the other. It is believed that some little or nothing modifiable factors such as age, poor education and low level support family or social'lead the patient to not show the symptoms of cervicovaginal infection in time, to introduce a condition that forces them to go to second-level care for threatened miscarriage, premature rupture of membranes and even preterm birth. On the other hand, abortion in this population as reported in United States has a high prevalence ${ }^{5,14}$ values that duplicate the prevalence not adolescent pregnant in other countries. ${ }^{14}$ The majority of abortions in this study and in the world, occur in the first trimester of pregnancy and very little is known of this etiology, chromosomal abnormalities play a role and maternal age is the only preacher of abortion ${ }^{14}$ explained by physiological immaturity. 
The treat of preterm labor and preterm delivery have the same prevalence in this population, ${ }^{8,15,16}$ comparison of prevalence with pregnant adults is controversial, some studies identify similar prevalences, ${ }^{17}$ originating from the explanation to genitourinary infections, however, otherstudies indicate that the threat of birth preterm and preterm delivery is higher in pregnant adolescents and the explanation is due to the immaturity of the female reproductive system. ${ }^{1,15,16}$ In the studied population this condition prevails between the 31 y 33 weeks of gestation and there is not a study where it is mentioned. Faced with this panorama, the recommendation is the timely identification and treatment of genitourinary tract symptoms.

In this study, premature rupture of membranes behaves in manner similar to that reported in pregnant adults, ${ }^{17}$ however, there is a report in Mexican population that designates a prevalence higher than found. ${ }^{18}$ We know that premature rupture of the membranes amnion is the occurrence of the event before the onset of labor. There is no report in the literature about the week of pregnancy that occurs with higher prevalence. It is known that this group age is due to ascending genitourinary infections, followed by the immaturity of the female genital tract, so it is recommended to place emphasis on the timely detection, as well as the cultivation of vaginal discharge; but above all it is important to identify that occurs, due to the different needs of timely treatment both in the mother and in the product. On the other hand, the prevalence of preeclampsia/eclampsia in this study is lower than what was reported in the international literature for adult pregnant women, ${ }^{19}$ although is known that hypertensive disorders of pregnancy prevailing in less than age 19 and over 35 years of age, the exact etiology is not known, but it is believed due to the poor implementation and irrigation of the same, endothelial dysfunction resulting in microthrombus and the inadequate tissue oxygenation, resulting elevation of figures of maternal blood pressure and intrauterine growth restriction of the product. Arguably then, the adolescent population pregnant with this condition is less than in the pregnant women older than 35 years of other countries.

As for perinatal complications such as low weight, prematurity, neonatal jaundice and hyaline membrane disease, is observed in this study are lower than what was reported in the rest of the Mexican adolescent population, ${ }^{20}$ and the babies are healthy according to anthropometric characteristics and estimation of the apgar punctuation at 5 minutes; this tell us that the teenage mother's newborn is well tolerated childbirth and that requires only routine postpartum care measures. Thus, there is, that the resolution of the pregnancy through childbirth at this age group is prevalent, with one little higher with respect to other countries as United States incidence, even Mexican population. ${ }^{1,20,21}$ Therefore, it is recommended whenever and wherever possible, pregnancy vaginal resolution emphasizing the benefits both to the mother as for the newly born this way from birth, and thus further reduce rates of birth by caesarean section. ${ }^{1,18,20}$ In conclusion, we identified the obstetric complications prevalence and gestational age of presentation in pregnant adolescents, and the observed results was different than the international literature, and that knowing the week of gestation of presentation of the complications can be prevented by education to the adolescent pregnant patient, or otherwise prepare the doctor of the first contact in the presence of such complications in non-satisfactory evolution.

\section{Acknowledgments}

None.

\section{Funding sources}

The research was carried out with the Institution's own funds. There was no external financing.

\section{Conflicts of interest}

The author declares there is no conflict of interest.

\section{References}

1. Seince N, Pharisien I, Uzan M. Embarazo y parto en adolescentes. EMCGinecología-Obstetricia. 2008;44(3):1-7.

2. Loredo-Abdalá A, Vargas-Campuzano E, Casas-MuñozA, et al. Embarazo adolescente: sus causas y repercusiones enel adiada. Rev MedInst Seguro Soc. 2017;55(2):223-229.

3. Gobierno de la República. Estrategia Nacional para la prevención del embarazo en adolescentes. México. 2017. p. 1-128.

4. Huanco D, Ticona M, Ticona M, et al. Frecuencia y repercusiones maternas y perinatales del embarazo en adolescentes atendidas en hospitales del Ministerio de Salud del Perú, año 2008. Rev Chil Obstet Ginecol. 2012;77(2):122-128.

5. Dainne S, Felice E, Felice M. Gestación en adolescentes. Parte XIII. Medicina de la adolescencia. En: Kliegman R, editors. Nelson Tratado de Pediatría.19 edición, Editorial Elsevier. 2013. p. 1025-1029.

6. Gaete V. Desarrollo psicosocial del adolescente. Rev Chil Pediatr. 2015;86(6):437-443.

7. Tapia H, Iossi MA, Pérez I, et al. Perfil obstétrico de adolescentes embarazadas en un hospital público: riesgo al inicio del trabajo de parto, parto, pós-parto y puerperio. Rev Latino-Am Enfermagem. 2015;23(5):829-836.

8. Vázquez Á, Guerra C, Herrera V, et al. Embarazo y adolescencia: Factores biológicos materno y perinatal más frecuentes. Rev Cubana Obstet Ginecol. 2001;27(2):158-164.

9. Muñoz M, Oliva P. Los estresores psicosociales se asocian a síndrome hipertensivo del embarazo y/o síntomas de parto prematuro en el embarazo adolescente. Rev Chil Obstet Ginecol. 2009;74(5):281-285.

10. Cox S, Reid F. Urogynecological complications in pregnancy: an overview. Obstetrics Gynaecology \& Reproductive Medicine. 2018;28(3):78-83.

11. Villalobos-Hernández A, Campero L, Suárez-López L, et al. Embarazo adolescente y rezago educativo: análisis de una encuesta nacional en México. Salud Publica Mex. 2015;57(2):135-143.

12. Narayan B, Nelson-Piercy C. Acute medical complications of pregnancy. Medicine. 2017; 45(3):125-130.

13. Cuero MR, Varelas PN. Neurologic complications in pregnancy. Crit Care Clin. 2016;32(1):43-59.

14. Zamora-Lares AN, Panduro-Barón JG, Pérez-Molina JJ, et al. Embarazo en adolescentes y sus complicaciones materno perinatales. Revista Médica MD. 2013;4(4):233-238.

15. Demirci O, Yilmaz E, Tosun Ö, et al. Effect of young maternal age on obstetric and perinatal outcomes: results from the tertiary center in Turkey. Balkan Med J. 2016:33(3):344-349.

16. Manrique R, Rivero A, Ortunio M, et al. Partopretérmino en adolescentes. Rev Obstet Ginecol Venez. 2008;68(3):141-143.

17. Instituto Nacional de Estadística y Geografía. Indicador trimestral de la actividad económica estatal. Durante el segundo trimestre de 2017. Cifras desestacionalizadas. Comunicado de Prensa. 2018. p. 1-18. 
18. Cruz HO, Plascencia JL, Nakashimada AI, et al.Causas de nacimiento pretérmino entre madres adolescentes. Ginecol Obstet Mex. 2007;75(1):17-23.

19. Graham A, Devarajan S, Datta S. Complications in early pregnancy. Obstetrics Gynaecology and Reproductive Medicine. 2015;25(1):1-5.

20. Baeza B, Póo AM, Vásquez O, et al. Identificación de factores de riesgo y factores protectores del embarazo en adolescentes de la novena región. Rev Chil Obstet Ginecol. 2007;72(2):76-81.
21. Medhi R, Das B, Das A, et al. Adverse obstetrical and perinatal outcome in adolescent mothers associated with first birth: a hospital-based casecontrol study in a tertiary care hospital in North-East India. Adolesc Health Med The. 2016;7:37-42. 